\title{
Exploration and practice in-class practice teaching mode
}

\author{
Xue-Ping Zang, Wei-Feng Wu
}

Xue-Ping Zang, Wei-Feng Wu, "Exploration and practice in-class practice teaching mode," Proc. SPIE 10452, 14th Conference on Education and Training in Optics and Photonics: ETOP 2017, 1045213 (16 August 2017); doi: $10.1117 / 12.2269569$

SDIE Event: 14th Conference on Education and Training in Optics and Photonics, ETOP 2017, 2017, Hangzhou, China 


\title{
Exploration and practice In-class practice teaching mode
}

\author{
Xue-Ping Zang*, Wei-Feng $\mathrm{Wu}$ \\ School of Mechatronic Engineering, Chizhou University, Chizhou 247000, China
}

\begin{abstract}
According to the opto-electronic information science and engineering professional course characteristics and cultivate students' learning initiative, raised the teaching of photoelectric professional course introduce In-class practice teaching mode. By designing different In-class practice teaching content, the students' learning interest and learning initiative are improved, deepen students' understanding of course content and enhanced students' team cooperation ability. In-class practice teaching mode in the course of the opto-electronic professional teaching practice, the teaching effect is remarkable.
\end{abstract}

Keywords: In-class practice, Educational reform, Opto-electronic information science and engineering

\section{INTRODUCTION}

The 21 st century is the century of light, the opto-electronic industry is the most attractive sunrise industry. Optoelectronic technology is a cross disciplines and it is a combination of optics, electronics, machinery and materials. Five professionals, which are opto-electronic technology science, opto-electronic information science and technology, optoelectronic materials and devices, information display and opto-electronic technology and opto-electronic information engineering, are merged into a opto-electronic information science and engineering. Opto-electronic information science and engineering professionals cultivates talents with in the field of opto-electronic information. In area-applicationoriented college, Many students lack the activity and initiative of the learning, they waste a lot of time playing net game and wechat. After graduation, the students' independent innovation ability is poor, the students' team cooperation ability and practical ability are weak. According to the above problems, this paper is focused on the students themselves, to cultivate students' initiative, to enhance students' awareness of participation, to train students' team spirit and make full use of students' extracurricular time. Starting from the teaching practice of opto-oelectric professional, we summed up the typical difficulties of the traditional teaching mode. The in-class practice teaching was introduced in the classroom teaching. According to the requirements of talent training program and curriculum, We design of different in-class practice content. It was proved that the in-class practice teaching has good effect in practice.

\section{DIFFICULTY OF TRADITIONAL CLASSROOM TEACHING MODE}

The traditional teaching is mainly based on the classroom teaching, and the effect of the teaching is not optimistic, there are many problems to be solved.

First, the content of teaching is constant, the proportion of theoretical content is more. In many professional classroom teaching, the proportion of theoretical content is more. Not only the teacher takes up most of the teaching time, but also the teaching knowledge is divorced from the practice. Second, single evaluation method. The course examination includes three aspects: the final exam scores, homework and student attendance, which can not reflect the reality of students' learning. The last, single teaching method. Teaching is given priority to with combination of traditional blackboard writing and PPT teaching, the teacher is only knowledge disseminator, the student is only the passive recipients of knowledge.

Summarized the above problem, because of the disadvantages of the traditional teaching, the students' learning interest is not strong, the studying initiative is reduced, the sense of participation is weak and the team spirit of students can not be trained. The current classroom teaching need reform, for this reason, we introduced the in-classroom practice teaching in the classroom in order to enriching the teaching form and improving the classroom teaching effect through the investigation.

*xpzang@mail.ustc.edu.cn

14th Conference on Education and Training in Optics and Photonics: ETOP 2017, edited by Xu Liu,

Xi-Cheng Zhang, Proc. of SPIE Vol. 10452, 1045213 · C 2017 ICO, IEEE, OSA, SPIE

CCC code: $0277-786 X / 17 / \$ 18 \cdot$ doi: $10.1117 / 12.2269569$

Proc. of SPIE Vol. 10452 1045213-1 


\section{TEACHING REFORM AND PRACTICE}

\subsection{In-classroom practice}

The in-classroom practice teaching is introduced in the classroom teaching of opto-electronic professional in order to improving the learning interest of the opto-electronic professional's student. According to the requirement of the optoelectronic professional training scheme, we designed different practical application of subject which closely linked with professional knowledge. Teachers divided the class into several groups to research for the related knowledge of the incalss practice, then students completed a research report according to the studying course and the professional knowledge. In the next in-class practice, each group elaborated and discussed the research report, and then let the teacher summarize. Teachers sometimes put forward some innovative experiment, students designed and complete the experiment, and then let teachers and students evaluated. In order to complete the in-class practice, students should carry out the investigation and discussion. Through in-class practice, the student interest of professional study is motivated, students' active learning ability and team cooperation ability are cultivated, the ability of literature consulting and analysis summary are improved, students' extracurricular life is enriched.

Part of our in-class practice topic: Monitoring speed by Doppler effect; Electromagnetic field and electromagnetic wave in the actual application research; Application of optical interference in precision measurement; Design of sun tracking system using solar energy; Principle and application of anti reflection film and high reflecting film; LED light cube design and production, and so on.

\subsection{Reform of curriculum evaluation}

In the traditional curriculum evaluation, the peacetime score is $30 \%$ and the final exam score is $70 \%$. The traditional curriculum evaluation emphasizes the result and weaken the learning process, it is difficult to arouse the enthusiasm of students' learning. Due to the introduction of in-class practice teaching, we propose the peacetime score in half and the final exam score. The peacetime score include $20 \%$ of the in-class practice, $15 \%$ of the class performance and $15 \%$ of homework. The class performance and homework are not less than three times, the in-class practice is not less than two times. In order to improve the students' understanding of the curriculum knowledge and enhance the students' awareness of the curriculum and professional, we raise the requirement of in-class practice and class performance.

\section{SUMMARY}

Through the introduction of the in-class teaching, the teaching of the course of photoelectric professional has got good effect. The teaching reform has improved the students' learning initiative, enhanced the students' awareness of participation, cultivated the team spirit of the students and made full use of the students' spare time. Next we would improve the quality of the in-class practice, so that the in-class practice can mobilize the enthusiasm of the most students, and make the in-class practice for the most of students benefit from it.

\section{ACKNOWLEDGMENTS}

This work is supported by the Key Program of the Outstanding Young Talent of Anhui Province under Grant No.gxyqZD2016370 and No.gxyqZD2016368, the Education project in Anhui Province under Grant No.2016jyxm0701.

\section{REFERENCES}

[1] Zhang, H. M. ,Shang, K. K., Gao, G., Wang, F. Z., "Exploration and Practice in Professional Training of Local University for the Major of Optoeledtronic Information Science and Engineering," Physics and Engineering, 25(2), 89-92 (2015).

[2] Zang, X. P., "Applied Undergraduate Colleges and Universities of Science and Engineering Physics Teaching Reform and Practice," Journal of Chizhou University, 29 (6), 140-141 (2015). 